
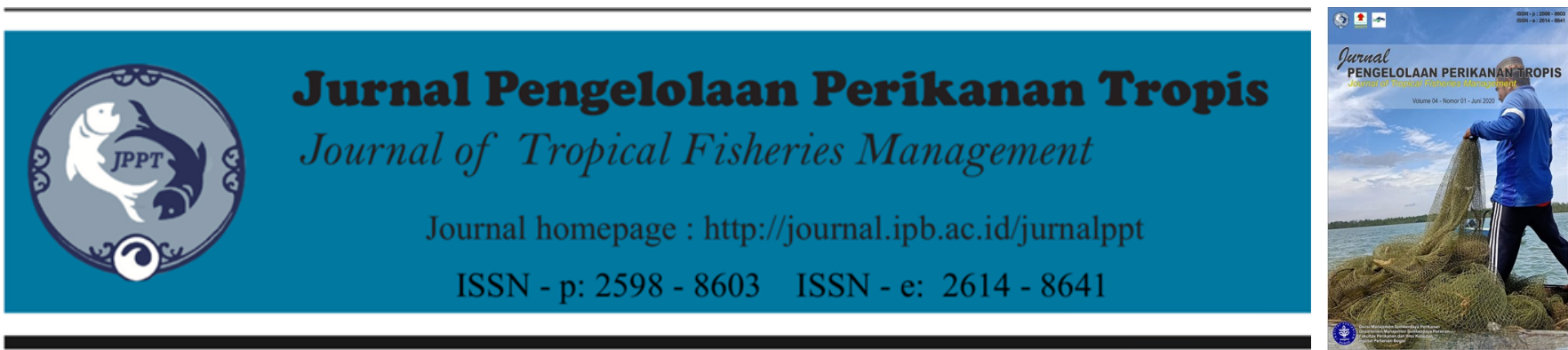

\title{
Analysis of Ecobiology of Green Sea Turtle (Chelonia mydas) and its Threatening factors in Citirem and Hujungan Coasts, Cikepuh Wildlife Reserve, Sukabumi, Indonesia
}

\section{(Analisis Ekobiologi Penyu Hijau (Chelonia mydas) dan Faktor-Faktor Pengancamnya di Pantai Citirem dan Hujungan, Suaka Margasatwa Cikepuh, Sukabumi, Indonesia)}

\section{Muhammad Irfan Afif ${ }^{1 *}$, Fredinan Yulianda ${ }^{2}$}

\author{
${ }^{1}$ Program Study of Aquatic Resources Management, Postgraduate School, IPB University
}

${ }^{2}$ Department of Aquatic Resources Management, Faculty of Fisheries and Marine Sciences, IPB University

\begin{tabular}{l} 
ARTIKEL INFO \\
\hline Article History \\
Recevied: 16 Maret 2020 \\
Accepted: 26 April 2020 \\
\end{tabular}

\section{Keywords:}

anthropogenic, endangered species, environment, turtle

\section{Kata Kunci:}

antropogenik, lingkungan,

kepunahan, penyu.

\section{Korespondensi Author}

Muhammad Irfan,

Department of Aquatic Resources

Management, Faculty of Fisheries

and Marine Sciences

Email:

muhammad_irfan@apps.ipb.ac.id

\section{ABSTRACT}

Green sea turtle (Chelonia mydas) is threatened species, included in the IUCN list with the endangered species category, and included in Appendix I in CITES which means that they are prohibited from being traded internationally. Cikepuh Wildlife Reserve located in Sukabumi Regency, West Java, is one of the conservation places where green sea turtles oftentimes lay their eggs. The objective of this study was providing useful baseline data of green sea turtle ecobiology and examine further factors that threaten their population. Serial observations were conducted annually since 2014 until 2018 by measuring the physical condition of coast and the morphological condition of green sea turtles. Results obtained from observations in each year showed the differences in total turtle nesting on both coast. In 2014, the nesting turtle ratio either in Citirem Hujungan obtained as much as 15:1(111.5 $\pm 1.64: 117 \mathrm{CCL} / 97 \pm 0.36: 101 \mathrm{CCW})$, while in 2018 is 4:0 (103.75 $\pm 2.32:-$ CL / 93.75 $\pm 3.92:-$ CCW $)$. Citirem coast is overgrown with many kinds of beach crops such as Pandanaceae, while at Hujungan coast, this plant does not grow widely. The threatened factors of green sea turtle occurring in Cikepuh Wildlife Reserve is mostly anthropogenic activities and predation. This needs to be an important highlight that turtle conservation needs to be carried out by integrated stakeholders that to form good management.

\section{ABSTRAK}

Penyu hijau (Chelonia mydas) adalah spesies yang terancam, termasuk dalam daftar IUCN dengan kategori spesies yang terancam punah, dan termasuk dalam Appendix I dalam CITES yang berarti dilarang diperdagangkan secara internasional. Suaka Margasatwa Cikepuh yang terletak di Kabupaten Sukabumi, Jawa Barat, adalah salah satu tempat konservasi di mana penyu hijau seringkali bertelur. Tujuan dari penelitian ini adalah memberikan data dasar yang berguna tentang ekobiologi penyu hijau dan memeriksa faktor-faktor lebih lanjut yang mengancam populasi mereka. Pengamatan temporal dilakukan setiap tahun sejak 2014 hingga 2018 dengan mengukur kondisi fisik pantai dan kondisi morfologi penyu hijau. Hasil yang diperoleh dari pengamatan di setiap tahun menunjukkan perbedaan dalam total penyu bersarang di kedua pantai. Pada tahun 2014, rasio penyu yang mendarat baik di Citirem - Hujungan diperoleh sebanyak 15:1 (111,5 $\pm 1,64: 117$ CCL $97 \pm$ 0,36: 101CCW) , sedangkan pada 2018 adalah 4:0 (103.75 \pm 2.32: - CL / $93.75 \pm 3.92$ : CCW). Pantai Citirem ditumbuhi banyak jenis tanaman pantai seperti Pandanaceae, sedangkan di pantai Hujungan, tanaman ini tidak tumbuh luas. Faktor-faktor pengancam penyu hijau yang berada di Suaka Margasatwa Cikepuh sebagian besar adalah aktivitas antropogenik dan factor predasi. Ini perlu menjadi sorotan penting bahwa konservasi penyu perlu dilakukan oleh para pemangku kepentingan yang terintegrasi untuk membentuk manajemen yang baik.

\section{INTRODUCTION}

The green sea turtle (Chelonia mydas, Linnaeus 1758) is one of six turtle species which breeds commonly in Indonesia shoreline (Limpus and Nicholls 1988). Green sea turtle classified as a long-lived reptile with a broad distribution ranging from tropical and subtropical oceans worldwide. The complex life cycle of green sea turtle had been a significant challenge to research because of the spatial and temporal factors are a major consideration. (Dethmers et al. 2006). Researching the population status of green sea turtle at coastal foraging areas is necessary for 
taking a step to conserve their existence. Santos et al. (2017) showed that green sea turtle is threatened with extinction and listed as endangered species by the International Union for Conservation (IUCN). Convention on International Trade in Endangered Species of Wild Fauna and Flora (CITES) also classified this species as Appendix I, which means the green sea turtle not be traded internationally. Moreover, based on Government Regulation of the Republic of Indonesia No. 7/1999 on Preserving Flora and Fauna Species, green sea turtle has also been listed as protected animals. Many factors affected the declining population of this species, including: 1.) Degradation, fragmentation, and loss of habitat, 2.) Unsustainable use of natural resources, 3.) Climate changes, 4.) Human activities (anthropogenic threats).

Cikepuh Wildlife Reserve is under the management of the Ministry of Environment and Forestry, Republic of Indonesia. This area was designated as a Wildlife Reserve based on the Decree of Ministry of Environment and Forestry of the Republic of Indonesia dated May, $8^{\text {th }}$ in 2014 No. SK.3685/Menhut-VII/KUH/2014. Cikepuh Wildlife Reserve has land area of approximately 8 hectares and the height of coverage area up to 250 meters above sea level (Polosokan 2010). The Cikepuh Wildlife Reserve is one of the current turtle conservation sites. This became the government's concern with the construction of turtle breeding. However, there are many factors that threaten the existence of turtles. The over-utilization of space near green sea turtle nesting in this area has also been suspected as reducing factor to the breeding sites (Ario et al. 2016). This study was conducted to provide baseline data of green sea turtle ecobiology and identify factors threatening their population in Cikepuh Wildlife Reserve. These data will be critical to improve better conservation practices in Cikepuh Wildlife Reserve.

\section{METHODS}

\section{Study site}

Cikepuh Wildlife Reserve located at the east of Palabuhan Ratu Bay and facing to the Indian Ocean (Figure 1). The boundaries between $7^{\circ} 11^{\prime}$ $7^{\circ} 20^{\prime} \mathrm{S}$ and $106^{\circ} 23^{\prime}-106^{\circ} 30^{\prime} \mathrm{E}$. The topography condition dominated by lowland, even there also several hills with slope variations. The average temperature is about $25.3^{\circ} \mathrm{C}$. The average surface water temperature is about $24.7^{\circ} \mathrm{C}$ with little temporal variation during the study period. The annual precipitation is about $3,585 \mathrm{~mm}$, mainly in the monsoon and typhoon seasons. The current tidal cycle is semi-diurnal, with amplitude ranges from 0.4 to $1.62 \mathrm{~m}$.

There are two coasts as green sea turtle main settlement, Citirem and Hujungan. A small cape separates the beach. Citirem Coast has more shoreline than Hujungan Beach, and also have a lower slope. Citirem Coast is still natural structured and not much disruption of various human activities. While, the human activity and disturbances such as illegal poaching, tourism activities, and others have been a fundamental problem for years in Hujungan Coast.

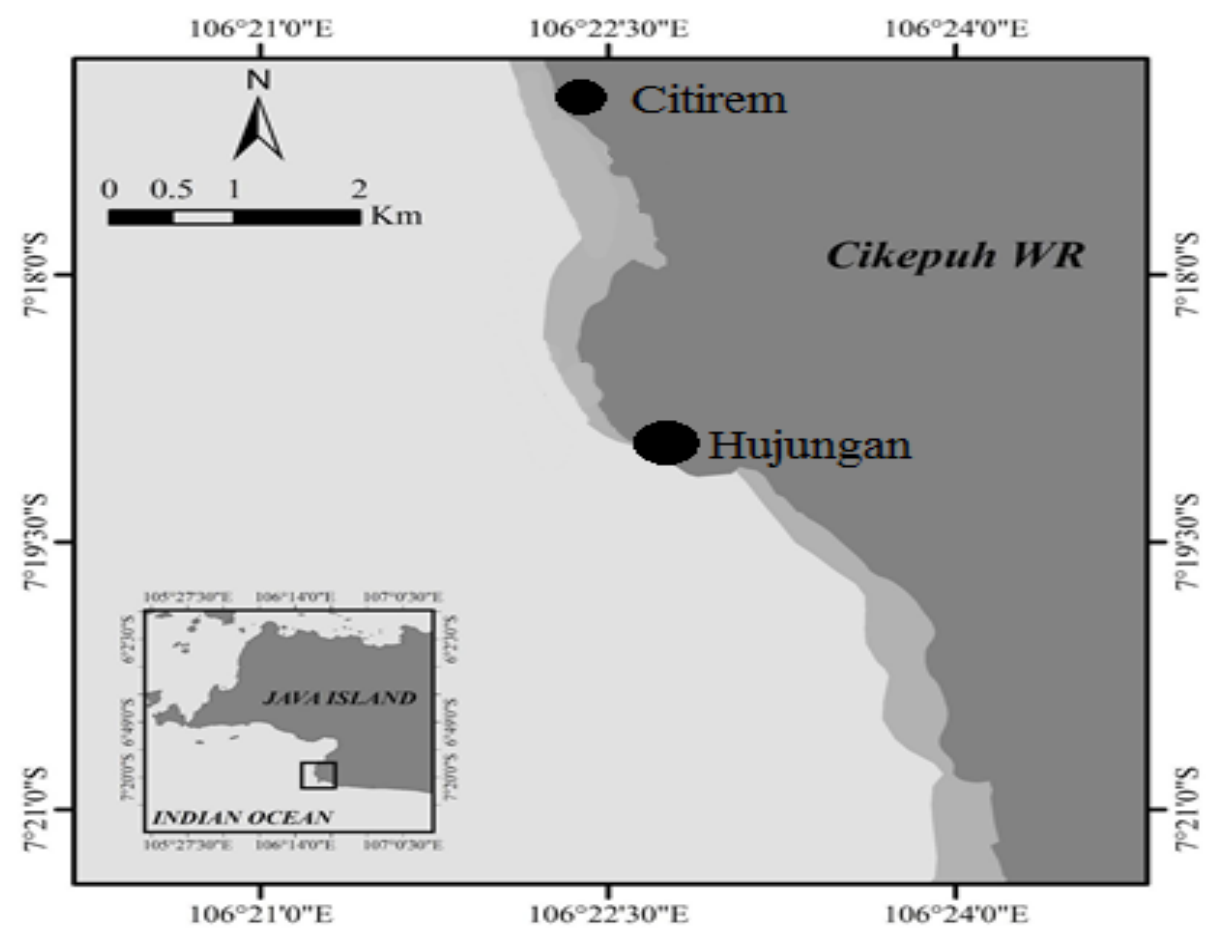

Figure 1. Location of Cikepuh Wildlife Reserve 


\section{Field observation}

This observation was conducted on August 2014, 2015, 2016, 2017 and 2018. According by the sanctuary guard, August is the month of the season for nesting turtle. Three types of a survey were conducted, intensive nocturnal survey, environmental survey, and social perception survey. The nocturnal survey occurred 5-7 days each month during a period of a survey at both coasts. The time of nocturnal survey started from 6:00 p.m. to 4:00 a.m. The survey team consisted of Atlantik and reserve guard, then divided into several small-groups that respond to the scope of an area (mostly $2 \mathrm{~km}$ of shoreline). For every encountered turtle, the morphological characteristics of the individual and nest parameters (clutch size, nest depth) were recorded. Location of nesting also was plotted with GPS (Garmin eTrex10) to make a spatial distribution of nesting preference. The physical survey occurred at the daytime in three stations, this survey is responsible for physical data of beach (slope, width), shoreline vegetation, intertidal vegetation and also crawl track that unidentified at a nocturnal survey. Social perception survey occurred 3-4 days each month, the subject of observation was a community of the closest village from the reserve and also the authority of reserve (head, staff, and guards).

\section{Data Collection and Analysis}

The size of nesting turtle was considered by measuring The Curved Carapace Length (CCL) and The Curved Carapace Width (CCW). CCL was measured with a fiberglass tape $(+0.5 \mathrm{~cm})$ along the middle line of the carapace from the front end of the nuchal scute to the rear end of the supracaudal scute. CCW was measured with the same tools at the middle of the turtle shell and perpendicular with CCL.

The nesting data includes nest depth, nest diameter, nest temperature, clutch size and an insitu sample of sand. Nest depth was determined with a fiberglass tape $(+0.5 \mathrm{~cm})$ from the beach surface to the deepest position in the nest. The diameter of nest determined with the same tools from the broad side of nest mouth. Nest temperature determined once the turtle had started laying eggs, a sand temperature at nest depth was recorded by carefully inserting the thermometer of a 30-cm-long. Compost thermometer $\left( \pm 1^{\circ} \mathrm{C}\right) 2$ $\mathrm{cm}$ deep into the bottom of the egg chamber. The clutch size was determined by digging out of nest within day-4 of nesting, and the total number of eggs was numerated. Every nest in Cikepuh Wildlife Reserve was relocated to avoid the tideflood, egg poaching, and natural predation. The in -situ sand was sampled with sediment cores (5.8 $\mathrm{cm}$ in diameter) after the turtle had nested. The cores were sealed at both ends and transported back to the laboratory for sediment analysis with sieve shaker (Retsch AS 200 Basic).

Hatching rate was calculated by the collected data. The formula from García-Grajales et al. (2019) was determined using the following parameters:

\section{[(total eggs - unhatched eggs)/total eggs] x 100}

Mean hatching success was calculated by hatchery and by year. As hatching rate is not a continuous variable, then the data directly interpreted.

Analysis of the data in this study was descriptive analysis. Descriptive analysis was used to view and present information from the data that has compared by the literature. The data from each measurements were made in the form of graphs and tables to facilitate the interpretation of results.

\section{RESULT AND DISCUSSION}

\section{Spatial distribution of nesting}

Spatial distribution of nesting works for mapping critical rookery area. After five years monitoring, the area of nesting occurred in 2 location. A different of the total turtle had showed and indicated that turtle always finds the suitable location for nesting. It can be a tool and make priority controlling zone for a nesting area. The narrow area of turtle nesting causes protection of turtle nesting areas to need to the priority controlling zone. Many factors that indicate this nesting are natural factor and anthropogenic factors.

Based on natural factor, usually, turtle makes a nest near vegetation of pandanaceae. A visual survey in Citirem Coast showed the most vegetation was Pandanus dubius and Pandanus tectorius. This plant may be intended to protect the nest from natural predators, stabilizes the substrate from shifting sand, and moisturizes the sand conditions (Gustian 1997). While in Hujungan Coast, the vegetation in general consisted of the type of Ipomoea pes-caprae, which is not preferred by green sea turtle because the roots of this plant complicate the turtle in digging the nest (Novitawati 2003).

The substrate type in Citirem and Hujungan Coasts also showed the differences. In Citirem, a plate coast formed naturally like a bay, white sandy, has a wide shoreline that is quite broad and very sloppy. This makes the area very suitable for spawning sea turtles on this beach. While in Hujungan, this coast is formed like a peninsula with a dominant arrangement of coral on the shores of the coast. The width of the coast of Hujungan is not as wide as Citirem. This makes the slope of the coast of Hujungan steeper $\left(5.36^{\circ}\right)$ than Citirem $\left(1.49^{\circ}\right)$. Following the research of 
Zavaleta-Lizarraga \& Morales-Mavil (2013), green sea turtles choose beaches to lay eggs easily accessed from the sea without obstacles such as rocks, steeper slopes or beach changes that prevent turtles from laying eggs, and the length and breadth of the beach.

Based on anthropogenic activities impact, Citirem Coast was very far from the reach of human activity. While in Hujungan, which is located on the outermost boundary of the conservation area, there were so many local people often passed this coast for many activities Weishampel et al. (2003) claimed that one factor that caused the declining of nesting activities of green sea turtle is that the turtles tend to avoid the area that indicates lots of human activities. Various human activities found at the study site were fishing and floating charts at night using additional lights to catch shrimp seeds. The free chart starts operating in the late afternoon until nearing dawn. The charts are widespread in the waters where the green sea turtle lands its eggs. This can interfere with the path and habits for turtles to reach the beach so they can lay eggs. Human activities at night especially the use of lights can affect the behavior of nesting turtle.

\section{Temporal distribution and size of nesting}

The secondary data from reserve authority (BKSA Jabar 2016) were collected to describe the temporal distribution of nesting green sea turtle. The number of nesting green sea turtle is decreasing in 30 years (Figure 2). According to Ferry et al. (2013) the cause of the ever decreasing green turtle population is caused by theft of eggs and sea turtles, increasing water traffic, which is increasingly crowded by fishermen and visitors and the amount of vegetation damaged by abrasion that results in the degradation of turtle habitat.

Related to the size of the nesting turtles, a five -year study was conducted to measure the green sea turtles. Fifty-five individual of green sea turtles were recorded during this study. The high number of turtles as peak season is in 2017. The result of the size of the nesting turtle shown in Table 2. The mean of CCL and CCW in every year not significantly different. The CCL more than $69.20 \mathrm{~cm}$ showed the mature turtle (Manginsela et al. 1986). According of nesting turtle size observation indicates that the turtle has reached maturity size. No one turtle that nested shorter than $69.20 \mathrm{~cm}$. It means that turtles in

Table 1. The difference of coast characteristics

\begin{tabular}{lll}
\hline Characters & Citirem & Hujungan \\
\hline Coast slope $\left({ }^{\circ}\right)$ & 1.49 & 5.35 \\
Coast width $(\mathrm{m})$ & 34.31 & 11.53 \\
Main vegetation & Pandanaceae & Convolvulaceae \\
Grain size $(\mu \mathrm{m})$ & \pm 500 & \pm 250 \\
Substrate & Sandy & Sand with coral \\
\hline
\end{tabular}

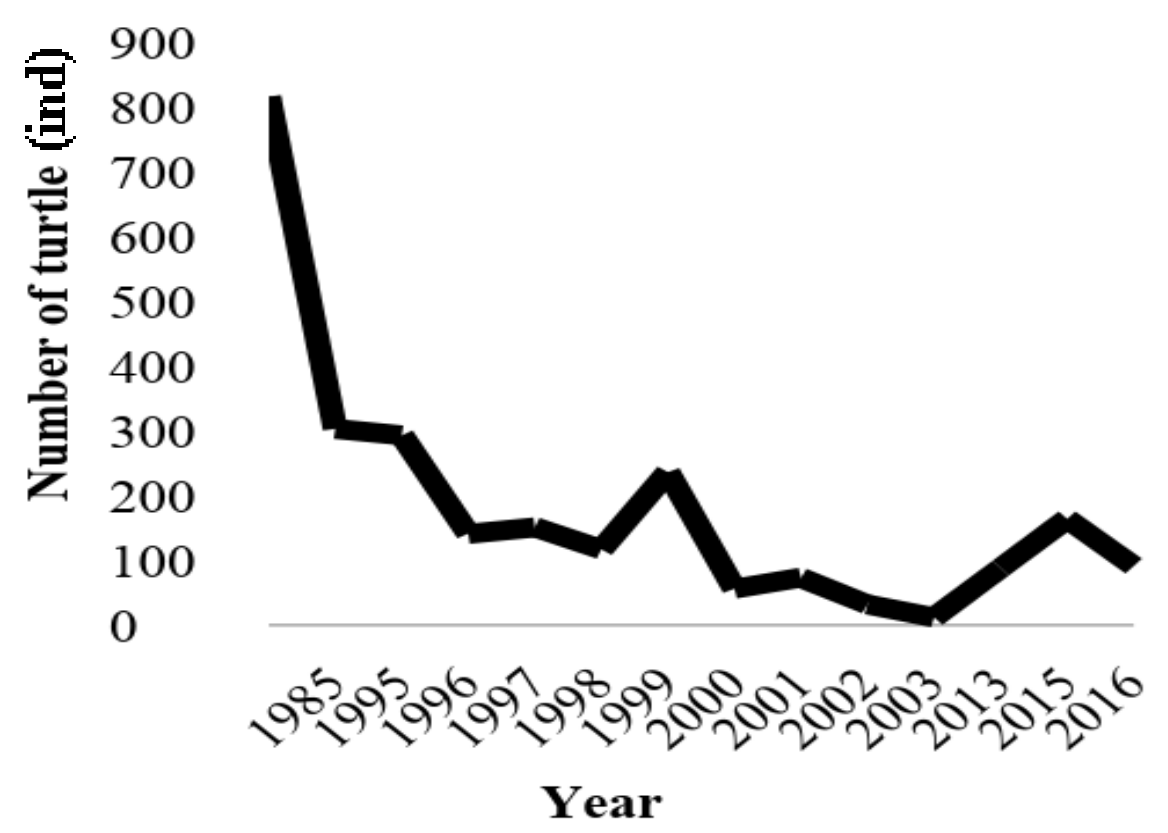

Figure 2. Green sea turtle nesting trend between 1985-2016 (Secondary data from BKSDA Jabar 2016) 
Cikepuh Wildlife Reserve still not subjected to the changes in reproductive patterns of green sea turtle despite there are some threats of extinction.

\section{Hatching}

The number of eggs shown in Table 3. the mean of the egg was variate. Too many factors that affected many laying eggs, sometimes turtle laying their egg separately. Based on the result of the hatching rate (HR) from annual secondary data shown in Table 3, the average of HR attained $78.44 \%$ with a semi-natural nest method. The egg hatchery success rate exceeds $50 \%$ is quite acceptable with attention to several factors to avoid predators (Ridla 2007). Sometimes, another factor that cause hatching failure are among others because of imperfect fertilization, restrained in the hive (imprisonment), disability or deformation (Bustard 1972). The semi-natural method in Cikepuh allows a better surveillance to avoid predators. However, the problem regarding the differences in the characteristics of seminatural nests with natural nests, the non-standard egg transfer process, and the presence of ant like inhibitors are of particular concern to the related authorities. So that is why it needs to develop the method to become more effective in incubating the eggs. The process of releasing hatchlings should also pay attention to the location of the hive's first nest, so the hatchlings released will be at the same point where they hatched.

\section{Management implementation}

Cikepuh Wildlife Reserve, as one of the green sea turtle (Chelonia mydas) habitat and one of the protected areas, has an area of 8,127 ha with only surveilled by 2-5 Forest Police and 5 guards. The surveillance system of the Cikepuh Wildlife Reserve area is carried out with a patrol security system that is only supported by facilities such as work huts, observation posts, and motorized vehicles. Security activities emphasized as prevention against theft of turtle eggs. Unfortunately, the theft of turtle eggs still in common. It caused by the lack of officers in maintaining a very large area of sanctuary.

Besides the lack of available resources and facilities, another problem faced by Cikepuh Wildlife Reserve is the difficulty of identifying priority issues and the amount of garbage stranded on the beach coming from Palabuhan Ratu Bay or Ujung Genteng. Cikepuh Wildlife Reserve was also faced with a lack synergy between the stakeholders of the Cikepuh Wildlife Reserve management area which directly caused low levels of communication in establishing cooperation and trust in surveillance green sea turtle (Chelonia mydas) habitat.

Another problem taking place in Cikepuh Wildlife Reserve is the low level of community

Table 2. Summary of measurements of green sea turtle in Cikepuh Wildlife Reserve 2014-2018

\begin{tabular}{lcccccc}
\hline \multirow{2}{*}{ Year } & \multicolumn{2}{c}{$\begin{array}{c}\text { Number of Green Sea } \\
\text { Turtle (ind) }\end{array}$} & \multicolumn{2}{c}{ CCL(cm) \pm SE } & \multicolumn{2}{c}{ CCW(cm) \pm SE } \\
\cline { 2 - 7 } & Citirem & Hujungan & Citirem & Hujungan & Citirem & Hujungan \\
\hline 2014 & 15 & 1 & $111.5 \pm 1.64$ & 117 & $97 \pm 0.36$ & 101 \\
2015 & 2 & 1 & $103.5 \pm 11.5$ & 108 & $90.5 \pm 6.5$ & 97 \\
2016 & 4 & 2 & $108.5 \pm 3.52$ & $107.5 \pm 9.5$ & $92.5 \pm 1.89$ & $93 \pm 8.0$ \\
2017 & 13 & 13 & $100.41 \pm 1.49$ & $105.15 \pm 2.02$ & $91.25 \pm 1.50$ & $93.35 \pm 1.79$ \\
2018 & 4 & 0 & $103.75 \pm 2.32$ & - & $93.75 \pm 3.92$ & - \\
Total & 38 & 17 & & & & \\
\hline
\end{tabular}

Table 3. Succession of total nesting turtle

\begin{tabular}{lll}
\hline Year & Mean of Total Eggs $\pm \mathbf{S E}$ & Mean of Annually Hatching Rate $\pm \mathbf{S E}$ \\
\hline 2014 & $130 \pm 7(60-160)$ & \\
2015 & $68 \pm 2(66-70)$ & $78.44 \% \pm 5.12$ \\
2016 & $68 \pm 9(59-104)$ & \\
2017 & $72 \pm 4(34-103)$ & \\
2018 & $64 \pm 7(53-88)$ & \\
\hline
\end{tabular}


participation in environmental awareness related to resource sustainability, which in this case will increase new threats that result in disrupting the stability of the security area of Cikepuh Wildlife Reserve. The number of problems faced is evident that the management efforts of the Cikepuh Wildlife Reserve area have not run effectively and efficiently. So that through these various problems, it is essential to form a collaboration forum for the development of Cikepuh Wildlife Reserve between the Regional Government, National, and International NGOs, as well as other stakeholders as an effort to strengthen management capacity. One form of collaboration that can be applied is the SMART (Spatial Monitoring and Reporting Tool) application developed by WCS (Wildlife Conservation Society). Also, it is essential to improve the method of implementing security in the form of preventive, repressive and participatory safeguards.

On the other hand, considering the extent of the supervision area, additional supervisory unit personnel are needed as well as procurement of supporting recommendations and infrastructure that are following the operating criteria. Efforts to manage Cikepuh Wildlife Reserve must also involve indigenous communities in joint patrols so that the level of resource security can be increased. Besides, further studies are needed regarding the evaluation of management effectiveness as an effort to find out what obstacles can hinder the process of achieving goals effectively and efficiently. According to Widiyanti (2016), a study on the evaluation of management effectiveness is significant in supporting the implementation of accountability and transparency in the management of conservation areas to the public.

\section{CONCLUSION}

In summary, our observations confirm the regional importance of the green sea turtles nesting on Cikepuh Wildlife Reserve and suggest that the status of the population is favorable. Despite in further, the difference of total nesting turtle between Citirem and Hujungan Coasts proves that there are natural factors and influences of human influence. It is clear that this remains an essential rookery for green sea turtles in West Java. However, additional monitoring is necessary to identify whether long-term trends in population size are occurring. The management of the area needs to be improved, with this baseline data. The managers can pay more attention to critical areas and maximize existing human resources to gain awareness towards sustainable development.

\section{REFERENCES}

Ario R, Wibowo E, Pratikto I, Fajar S. 2016. Preservation of turtle habitat from the threat of extinction at the Turtle Conservation and Education Center (TCEC), Bali. Journal of Tropical Marine. 19(1):60-66.

Bustard RH. 1972. Sea Turtle :Natural History and Conservation. Sidney (AUS): Collins, Press Inc.

Dethmers KM, Damien B, Craig M, Nancy N Fitzsimmons, Collins J L, Shane L, Scott W, Mick G, Robert ITP, Rod K. 2006. The genetic structure of Australian green turtle (Chelonia mydas): exploring the geographical scale of genetic exchange. Molecular Ecology. 15(13):3931-3946.

Ferry A, Syafruddin S, Sarma S. 2013. Habitat tempat bertelur penyu hijau (Chelonia mydas) di Kawasan Taman Wisata Alam Sungai Liku Kabupaten Sambas Kalimantan Barat. Jurnal Hutan Lestari. 1(2):156-163.

García-Grajales J, Meraz Hernando JF, Arcos García JL, Fuentes ER. 2019. Incubation temperatures, sex ratio and hatching success of leatherback turtles (Dermochelys coriacea) in two protected hatcheries on the central Mexican coast of the Eastern Tropical Pacific Ocean. Animal Biodiversity and Conservation. 42(1):143-152.

Gustian P. 1997. Analysis of the green turtle population structure (Chelonoa mydas) Female adult in the beach of Pangumbahan and Citirem area level II Sukabumi [thesis]. Bogor (ID): Institut Pertanian Bogor.

Limpus CJ, Nicholls N. 1988. The southern oscillation regulates the annual numbers of green turtle (Chelonia mydas) breeding around Northern Australia, Aust. J. Wild. Res. 15:157-161.

Manginsela FB, Mandey CFT, Subroto JSWD. 1986. Morfometik dan Berat Tubuh Penyu Hijau (Chelonia mydas) yang didaratkan Di Manado Provinsi Sulawesi Utara. Direktorat Jendral Pendidikan Tinggi: Departemen Pendidikan dan Kebudayaan.

Novitawati I. 2003. Study of the potential of sea turtle hatchlings in Taman Alam Sukawayana Beach, Pelabuhan Ratu, Sukabumi Regency [thesis]. Bogor (ID): Institut Pertanian Bogor.

Polosokan R. 2010. Type composition and 
structure of forest vegetation in the area of Cikepuh Wildlife Sanctuary, Sukabumi-West Java. Journal of Environmental Engineering. 11(2):147-155.

Ridla DA. 2007. Analisis Keberhasilan Penetasan Telur Penyu Hijau (Chelonia mydas L.) dalam Sarang Semi-Alami di pantai Pangumbahan, Kabupaten Sukabumi [skripsi]. Bogor (ID): Institut Pertanian Bogor.

Santos KC, Marielle L, Marianne F, Armando CL. 2017. Climate change implication for the nest site selection process and subquent hatching success of gren turtle population. Mitigate, Adapt, Strategy, Glob. Change. 22:121-135.

Weishampel JF, Bagley DA, Ehrhart LM, Rodenbeck BL. 2003. Spatiotemporal patterns of annual sea turtle nesting behaviors along an East Central Florida beach. Biological Conservation. 110(2):295-303.

Widiyanti H. 2016. Strategi Tata Kelola Pengembangan Ekowisata di Taman Wisata Alam Kawah Ijen Provinsi Jawa Timur[tesis]. Bogor(ID): Institut Pertanian Bogor.

Zavaleta-Lizárraga L \& Morales-Mavil JE. 2013. Nest site selection by the green turtle (Chelonia mydas) in a beach of the north of Veracruz, Mexico. Revista Mexicana de Biodiversidad. 84(3):927-937. 